\title{
Historical Review of The Origin of Pancasila as a Philosophical Basis for The Implementation of Pancasila Economic System
}

\section{P. Setia Lenggono}

Kepala Pusat Studi Ekonomi Pancasila, Universitas Trilogi Jakarta 12760, Indonesia setialenggono@trilogi.ac.id

\section{Article History}

accepted 09/04/2021

\begin{abstract}
The economic system is very important for a nation because it has two main functions, namely a guide to directing the economy and coordinating various economic activities carried out by economic actors with different preferences. This paper presents the Pancasila Economic System (read: SEP) as an economic system structured as a joint effort based on the principle of kinship. An important foundation in regulating and managing the national economy as mandated by the 1945 Constitution. By conducting a historical and philosophical review of the origins (ontology) of Pancasila which is the basis for thinking in formulating the epistemological and axiological foundations that should be the basis for implementing national economic development, this paper reveals that SEP is a "own system" that is uniquely Indonesian. A consensus from the founders of the state in realizing the ideals of independence, in order to create the greatest possible prosperity with all the people.
\end{abstract}

Keywords: origin, philosophical basis, Pancasila, economic system, historical reviews

\begin{abstract}
Abstrak
Sistem ekonomi menjadi sangat penting bagi sebuah bangsa karena memiliki dua fungsi utama, yaitu pedoman untuk mengarahkan perekonomian dan mengkordinasikan bermacam kegiatan ekonomi yang dilakukan pelaku ekonomi dengan preferensi berbeda-beda. Makalah ini mengetengahkan Sistem Ekonomi Pancasila (baca: SEP) sebagai tata ekonomi yang disusun sebagai usaha bersama berdasar atas asas kekeluargaan. Sebuah fundamen penting dalam mengatur dan mengelola perekonomian nasional sebagaimana diamanatkan UUD 1945. Dengan melakukan tinjauan historis dan filosofis atas asal-usul (ontologi) Pancasila yang menjadi pijakan berpikir dalam merumuskan landasan epistemologi dan aksiologi yang seharusnya menjadi dasar pelaksanaan pembangunan perekonomian nasional, makalah ini mengungkap bahwa SEP adalah sebuah"sistem sendiri" yang khas Indonesia. Sebuah konsensus dari para pendiri negara dalam rangka mewujudkan cita-cita kemerdekaan, guna menciptakan sebesar-besarnya kemakmuran bersama seluruh rakyat.
\end{abstract}

Kata kunci: asal-usul, dasar filosofis, Pancasila, sistem ekonomi, dan tinjauan historis

Social, Humanities, and Education Studies (SHEs): Conference Series https://jurnal.uns.ac.id/shes

p-ISSN 2620-9284 e-ISSN 2620-9292 


\section{PENDAHULUAN}

Hampir setiap negara-bangsa yang ada di dunia ini memiliki pandangan hidup dan sistem kehidupan yang berbeda. Perbedaan pandangan hidup dan sistem kehidupan tersebut dilatarbelakangi oleh akar budaya, sistem sosial ekonomi, dan letak geografis dan yang berlangsung dalam rentang sejarah yang panjang. Perbedaan pandangan dan sistem kehidupan tersebut pada akhirnya mengkristal dalam kehidupan sosial ekonomi masyarakat bersangkutan yang pada gilirannya membentuk sebuah peradaban tersendiri yang khas. Kekhasan peradaban tersebut bukan hanya disebabkan oleh faktor internal (budaya, etnik, sistem sosial, dan geografi) yang bersifat orisinal, melainkan juga dipengaruhi oleh faktor-faktor eksternal karena telah berinteraksi dan berakulturasi dengan beragam sistem filsafat, sistem sosial, sistem ekonomi, dan budaya baru.

Demikian halnya Bangsa Indonesia dapat mencapai kemerdekaan dan mampu bertahan sebagai sebuah bangsa hingga kini, karena memiliki sistem nilai yang khas. Dengan keyakinan seperti itulah, --para pendiri negara, ketika membentuk NKRI-memikirkan dan melahirkan "sistem sendiri" dalam menata kehidupan berbangsa dan bernegara baik dalam sistem politik-pemerintahan maupun ekonomi dan sosial lainnya. "sistem sendiri" tersebut, tidak hanya didasarkan kepada sistem yang telah berkembang sebelumnya di dunia, melainkan juga digali dari akar budaya (adat), sistem sosial, serta sistem ekonomi yang telah hidup dan berkembang secara turuntemurun yang melekat dalam falsafah hidup manusia (entitas) yang membentuk negara-bangsa Indonesia.

Makalah ini mengetengahkan SEP sebagai tata ekonomi yang disusun sebagai usaha bersama berdasar atas asas kekeluargaan. Sebuah fundamen penting dalam mengatur dan mengelola perekonomian nasional sebagaimana diamanatkan Pasal 33 UUD 1945. Makalah ini berupaya memberikan tinjauan historis dan filosofis atas asalusul (ontologi) yang menjadi pijakan berpikir dalam merumuskan landasan epistemologi dan aksiologi yang sepatutnya mendasari pengelolaan perekonomian Bangsa Indonesia.

\section{METODE}

Kajian dalam makalah ini menggunakan pendekatan historis, analisis isi (content analysis), framing, dan bahan-bahan (data dan fakta) dari sumber-sumber tekstual, hasil publikasi, dan informasi dari media-media kontemporer terkait hasil karya ilmiah para pemikir SEP dan hasil-hasil karya ilmuwan lain yang relevan. Adapun rujukan utama makalah ini bersumber dari pengembangan gagasan buku Sistem Ekonomi Pancasila (Tjakrawerdaja, Dkk., 2019), dimana penulis menjadi salah seorang penulis buku yang saat ini telah diajarkan dan menjadi mata kuliah wajib di Universitas Trilogi. Sedangkan analisisnya menggunakan analisis filosofis keilmuan dengan tiga pilar utamanya, yaitu ontologi, epistemologi, dan aksiologi yang bersumber dari Filasafat Pancasila.

Dengan semangat ingin membebaskan diri dari bias Indologi, tulisan ini ingin mengajukan suatu wacana pendekatan yang disebut dalam makalah ini sebagai eklektis-kolaboratif, yaitu upaya untuk menggabungkan hal terbaik dari pengetahuan filsafat lokal (etnik-etnik Nusantara) dan pengetahuan filsafat ilmiah dari dunia Barat dan Timur lainnya. Dimana hubungan-hubungan sosial lokal/Timur dipandang sebagai embedded dalam hubungan-hubungan sosial Barat, begitupun sebaliknya. Notonagoro (1975), menyebutnya sebagai metode eklektis inkorporatif, yaitu langkah-langkah metodis untuk menerima ilmu pengetahuan modern dari luar, tetapi dengan melepaskan dasar sistem filsafatnya dan selanjutnya diinkorporasikan atau disintesiskan ke dalam struktur filsafat Pancasila.

Sejauh ini filsafat didefinisikan secara subjektif oleh tiap-tiap filsuf, sehingga kesannya tidak ada tolok ukur tertentu yang harus disepakati bersama secara pasti. Di 
Barat, filsafat berkaitan erat dengan suatu pemikiran rasional untuk memperoleh pemahaman akan diri, hidup dan kehidupannya, serta rnenarik makna bagi "adanya" dalam keseluruhan. Sementara Timur mempunyai cara pendekatan yang (sama sekali) berbeda, yakni bukan lagi mengandalkan akal budi, melainkan intuisi atau bisikan hati, sehingga ketajaman rasa untuk mengetahui dan memahami segalanya menjadi menentukan (Kartika, 2004). Masing-masing memiliki pilihan yang disesuikan dengan pandangan hidup, kepentingan, dan keyakinan yang telah terbangun di dalam dirinya selama ini. Dengan asumsi seperti itu, makalah ini menawarkan keberadaan realitas berdasarkan prinsip identitas manusia Indonesia, yang menjadi prinsip tertinggi dalam rangka dan upaya memahami sesuatu, yaitu cita-cita kemerdekaannya; merdeka, bersatu, berdaulat, adil dan makmur.

Sebuah ruang yang diharapkan mampu menjelaskan bagaimana secara historis, nilai-nilai sosial tertentu berkembang dan kepentingan-kepentingan apa yang berkelindan, memungkinkan pamahaman berbagai aliran filsafat yang berjumpa dengan tradisi budaya (etnik) lokal dalam kepluralannya. Mambuka ruang bagi masuknya kekayaan campuran, pluralitas nilai hubungan sosial, meskipun konsekuensinya jatuh pada ketidakjelasan. Sebagaimana dikatakan Irwan (1999), salah satu indikator pendekatan bersifat historis adalah semakin tingginya tingkat ketidakpastian dan semakin terungkapnya kepentingan-kepentingan yang ada dibalik berbagai simbol-simbol budaya dan nilai sosial. Melalui pendekatan seperti ini, menjadi relavan untuk mempertanyakan kembali bagaimanakah asal-usul Pancasila sebagai ideologi bangsa menjadi dasar filosofis pelaksanaan SEP?

\section{HASIL DAN PEMBAHASAN \\ 1. Hakekat Manusia Indonesia Sebagai Ontologi Pancasila}

Sejauh ini filsafat didefinisikan secara subjektif oleh tiap-tiap filsuf, sehingga kesannya tidak ada tolok ukur tertentu yang harus disepakati bersama secara pasti. Dengan demikian, filsafat bukan hanya milik Barat, melainkan milik manusia di belahan bumi mana pun sejauh berkemauan untuk merenungkan makna eksistensi dan tujuan hidupnya, termasuk manusia Nusantara. Mengapa Nusantara? Karena yang membentuk kelndonesiaan saat ini adalah entitas-entitas dan mereka yang belakangan tinggal dan menetap di dalamnya.

Membicarakan keberadaan filsafat Nusantara, tidak mungkin tanpa memahami pentingnya prinsip identitas sebagai persoalan metafisis yang mendasari segala yang ada. Mengingat pemikiran Nusantara juga bagian dari realitas--- sementara keberadaan realitas berdasarkan pada satu prinsip, yaitu prinsip identitas, yang menjadi prinsip tertinggi dalam rangka dan dalam upaya memaharni sesuatu.

Realitas tersebut memaksa kita untuk menelisik lebih dalam, menyelami keberadaan manusia Nusantara. Nusantara adalah suatu wilayah yang tidak hanya melingkupi NKRI saat ini, tetapi juga wilayah negara lain di sekitar Lautan Pasifik dan Asia Tenggara yang masih mendapatkan pengaruh peradaban Melanesia (Papua), Austro Asiatik, dan Austronesia (Tjakrawerdaja, Dkk., 2019; Djafar, Dkk., 2020). Penutur Melanesia ---yang memiliki ciri kulit hitam dan rambut keriting berasal dari Afrika--- telah menghuni kepulauan Nusantara sejak 70.000 - 40.000 tahun silam. Orang Melanesia saat ini tersebar di NTT, Papua, Kepulauan Solomon, New Caledonia, Fiji hingga Australia. Selanjutnya, mereka bercampur dengan migran Austro Asiatik yang berasal dari Indo China sekitar 30.000 tahun yang lalu. Sementara, orang Austronesia bermigrasi ke Nusantara melalui Taiwan pada 6.000-5.000 SM. Percampuran dari ketiga peradaban inilah yang menurut Lembaga Biomolekuler Eijkman menjadi dasar pembentuk identitas manusia Indonesia 
Mereka melahirkan beragam wujud kebudayaan materil, sebagaimana manusia Jawa pesisir yang dapat merepresentasikan peradaban Austronesia, memproduksi banyak budaya asli sebelum dipengaruhi budaya Tiongkok dan India, tiga di antaranya; wayang kulit, orkestra gamelan, dan karya tekstil batik. Juga budaya tembikar, megalitikum, perladangan berpindah dan pertanian beririgasi yang dikembangkan peradaban Austro Asiatik. Sementara, budaya tenun ikat, seni ukir, menginang dan pengolahan sagu dikembangkan dan merepresentasikan peradaban Melanesia. Semua budaya materiil itu merupakan upaya paling awal untuk membangun tradisi metafisika, etika, kosmologi, dan kosmogoni spekulatif yang kian kritis dan sistematis yang menjadi dasar bangunan filsafati masyarakatnya di kemudian hari.

Keberadaan peradaban manusia Nusantara dapat dilacak berdasarkan lingua-franca Indo-Melayu yang dituturkan masyarakat Austronesia yang begitu dominan pengaruhnya di Nusantara. Peradaban mereka tersebar dari Madagaskar hingga Easter Island, serta dari Taiwan hingga New Zealand. Membentuk kawasan diaspora yang menjadi area jelajah para pelaut Nusantara pada masa lampau. Bisa dibayangkan betapa luasnya proses diaspora dan daya jelajah para pelaut Nusantara pada masa lampau. Sebuah proses kolosal sejarah yang ikut membentuk manusia Indonesia yang tampak seperti sekarang. Pelaut Nusantara tidak hanya menaklukkan samudra jauh sebelum bangsa Eropa, Arab dan Cina memulai penjelajahan bahari mereka, namun juga menjadikan nenek moyang Bangsa Indonesia sebagai penyokong awal gerakan globalisasi di muka bumi ini.

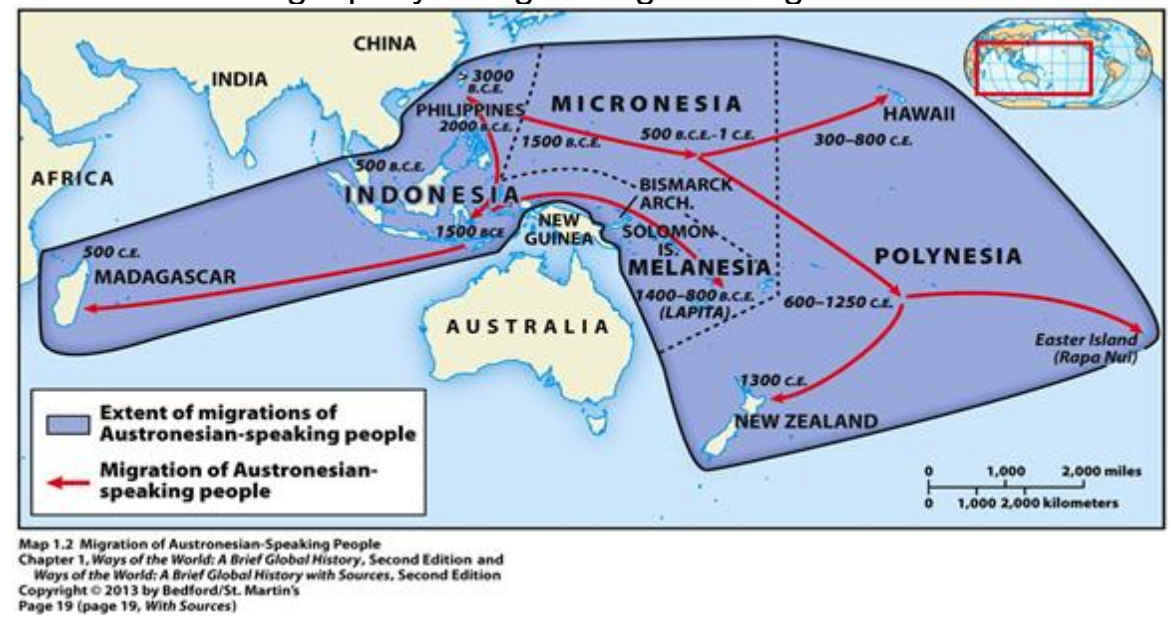

\section{Gambar 1. Peta Migrasi Penutur Austronesia Sumber: Bedford/St. Martin's (2013)}

Nusantara sebagai negeri maritim yang memiliki rangkaian pulau terbanyak di dunia dengan posisi geografis yang sangat strategis, digambarkan Dennys Lombard sebagai "Le Carrefour Javanais". Sementara Antony Reid menggambarkannya sebagai "Tanah di Bawah Angin". Tidak hanya membawa berbagai peradaban besar Timur merasuk ke jantung Nusantara, sebagaimana peradaban Hindu dan Budha dari India yang melakukan penetrasi hampir bersamaan dengan tumbuhnya Kerajaan Kutai Martadipura sebagai kerajaan Hindu tertua, hingga Kerajaan Tarumanegara, dan Majapahit. Selanjutnya peradaban Budha dibawa pengaruh Kerajaan Kalingga, Mataram Budha hingga Sriwijaya. Berikutnya muncul peradaban Islam yang masuk melalui Kerajaan Perlak - Samudra Pasai, Goa, Demak hingga Mataram Islam dan seterusnya. Sementara peradaban Cina melalui ajaran Taoisme dan Confusianisme ikut mewarnai dihampir semua sendi kehidupan kerajaan-kerajaan yang pernah ada. Kekayaaan sumberdaya alam Nusantara pun menjadi daya pikat masuknya peradaban Barat melalui penetrasi perdagangan dan kolonialisme dengan semangat 3G-nya 
(Gold, Glory, and Gospel). Menjadikan Nusantara sebagai tempat yang paling subur diatas muka bumi dalam "proses pemberadaban" umat manusia.

Peradaban Nusantara dengan segala keunikan karakteristiknya, telah menempuh rute/trajektori yang berbeda-beda secara geografis dan historis sejak masa lampau, tidak hanya diwarnai namun juga ikut mewarnai pertumbuhan peradaban lain di dunia. Dick-Read (2008), mengungkapkan bukti-bukti mutakhir bahwa para pelaut Nusantara telah menaklukkan samudra jauh sebelum bangsa Eropa, Arab dan China memulai zaman penjelajahan bahari mereka. Sejak Abad ke-5 $\mathrm{M}$, para pelaut Nusantara telah mampu menyebrangi Samudra Hindia hingga mencapai Afrika. Mereka bukan hanya singgah di Afrika, mereka juga meninggalkan banyak jejak pada kebudayaan di pantai timur Afrika. Memperkenalkan jenis-jenis tanaman baru, teknologi, musik dan seni yang pengaruhnya masih bisa ditemukan dalam kebudayaan Afrika sekarang.

Dengan dasar peradaban yang berbasis budaya bahari, masyarakat Nusantara memiliki cara penyikapan "tersendiri". Mereka memiliki satu cara hidup yang begitu kuat, berlanjut, dan sintas, bahkan lebih dulu dari banyak bangsa yang dianggap besar oleh dunia, bahkan oleh agama-agama besar dalam sejarah manusia. Mereka mampu bertahan, meskipun banyak etnik atau suku bangsa di dunia mengalami kepunahan atau terkuburkan oleh budaya baru yang ekspansif dan dominatif (Dahana, 2016). Padahal Bellwood (2000) memperkirakan jumlah rumpun bahasa Austronesia mencapai sekitar 1.200. Menjadikannya sebagai rumpun bahasa dengan jumlah anggota terbesar di dunia dan paling luas sebarannya, meliputi lebih dari separo dunia. Mereka sangat agresif, ulung dalam pelayaran (memiliki teknologi pelayaran) dan gemar bermukim di kawasan kepulauan, sehingga memiliki sebaran penutur terbanyak dan terluas di Pasifik - Samudra Hindia.

Tidak berlebihan jika Radhar Panca Dahana menyebut manusia Nusantara sebagai makhluk komunal sejati, homo socius, sebagaimana dibayangkan filsuf-filsuf bahari di Yunani dan filsuf Kontinental yang mengadopsinya. Tidak memusat atau sentralistik sebagaimana pemahaman Kontinental yang didasarkan pada perspektif atau keseimbangan antara kanan-kiri, hitam-putih, atas-bawah, yin-yang, manicheanisme (melukiskan satu pihak sebagai "baik" dan yang lain sebagai pihak "jahat") yang terlalu menyederhanakan, sehingga kerap terjebak dalam ideologi, bahkan ilusi. Manusia Nusantara justru mengusung semangat egalitarian, majemuk, menyebar, kosmopolitan dan outward looking khas Maritim. Kesadaran komunal seperti itu menciptakan sikap yang akseptan dan terbuka pada kehadiran orang lain (liyan), bahkan pada tingkat tertentu yang liyan akan menjadi bagian integral dari eksistensi personalnya. Tiap orang (suku bangsa) membutuhkan orang (suku bangsa) lain untuk meneguhkan keberadaan, bahkan bagi keberlanjutan hidupnya.

Hal itu menjadi kesadaran kolektif yang sangat dibutuhkan dalam proses pengintegrasian (baca: kesatuan) atas keberagaman masyarakat yang hidup dan menetap di Nusantara. Sebagaimana Hilderd-Geertz mengungkap keberadaan 300 etnis dengan identitas budaya berbeda-beda di Indonesia, ataupun temuan MA Jaspan yang memperkirakan adanya 366 etnis dengan kriteria pembeda pada bahasa daerah, kebudayaan serta susunan masyarakatnya. Demikian halnya Koentjaraningrat yang mengidentifikasi 195 suku bangsa di wilayah Indonesia. Jauh sebelumnya, Vollenhoven dalam studinya membagi etnik-etnik di Hindia Belanda ke dalam 19 lingkungan hukum adat (rechtskringen) dalam satu daerah dengan garis-garis besar, corak, dan sifat hukum adat yang seragam

Lebih jauh Holleman berhasil mengidentifikasi adanya satu kesatuan dari empat corak hukum adat di Hindia Belanda yang dapat merepresentasikan "pancaran dari jiwa dan struktur masyarakat Indonesia" yang justru menjadi perekat persatuan diantara perbedaan yang ada. Dengan dasar pemahaman filosofis seperti itu, maka 
yang muncul dalam praksis kehidupan manusia Nusantara bukanlah perbedaan yang lebih memiliki konotasi negatif terhadap kesatuan, namun justru yang mengemuka adalah keragaman yang diinsyafi manusia Nusantara sebagai kesatuan yang tidak terpisahkan dalam pergaulan sosialnya. Suku bangsa di Nusantara memandang bahwa dalam pergaulan hidupnya, manusia tidak bersifat individu yang berdiri sendiri, bebas dari ikatan kelompoknya dan hanya mencari manfaat bagi dirinya. Melainkan, manusia yang merupakan bagian dari kelompok dan baru mempunyai arti, jika ia bersama-sama dalam kelompoknya.

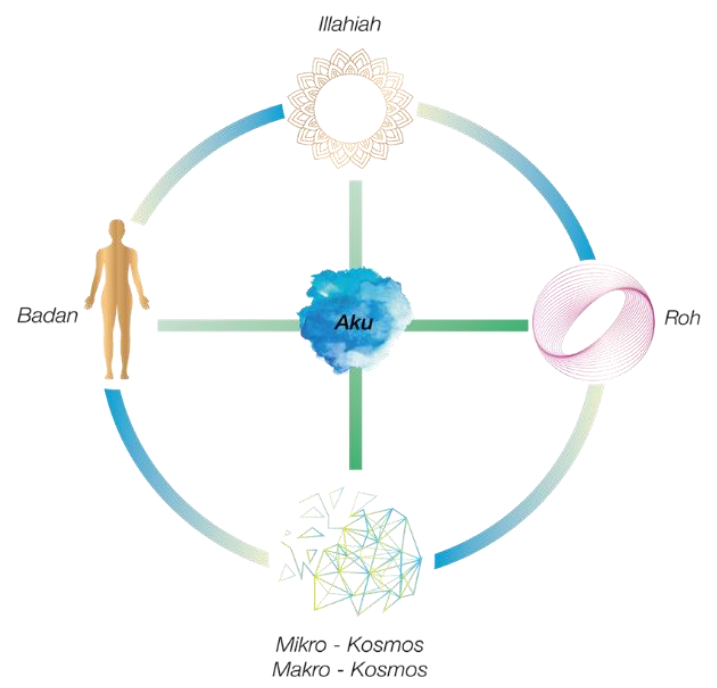

Gambar 2. Hakekat Eksistensi Manusia Nusantara

Eksistensinya ditempatkan pada keluhuran harkat dan martabat yang secara illahiah merupakan mahluk Tuhan YME dengan kesadaran mengemban kodrat relasional untuk selalu menempatkan diri dalam keselarasan masyarakat dan mikrokosmos - makrokosmos. Pandangan tersebut didasarkan atas pemikiran bahwa manusia merupakan mahluk pribadi (individu) sekaligus mahluk sosial yang tersusun atas kodrat jiwa dan raga, serta jasmani dan rohani. Sebagaimana diilustrasikan Serat Centini bahwa "tunggal tan tunggal lawan ing pesti, loro tan loro, jiwa tinon lawan ragane... (kita adalah tunggal tetapi tidak tunggal, dua namun tidak dua, jiwa menampakan diri dalam tubuh...).

Realitas seperti itulah yang mendasari gagasan filosofis yang dalam makalah ini disebut sebagai "Filsafat Etnik Nusantara" (baca: FEN), yaitu segala warisan pemikiran asli yang terdapat dalam adat-istiadat dan kebudayaan semua kelompok etnik di Nusantara. Sebuah wilayah yang tidak hanya melingkupi NKRI saat ini, tapi juga wilayah negara lain di sekitar Lautan Pasifik - Hindia dan kawasan Asia Tenggara yang masih mendapatkan pengaruh percampuran peradaban Melanesia, Austro Asiatik, dan khususnya peradaban Austronesia.

Keberadaan FEN tidaklah hidup, tumbuh dan berkembang dalam ruang hampa dan statis, kebal terhadap pengaruh peradaban asing, serta suci dari unsur filosofis asing. Dengan segala kelemahan dan kelebihannya, FEN beradaptasi, mengolah dan berinteraksi (saling mempengaruhi) dengan berbagai aliran filsafat yang berjumpa dengannya di aras lokal, sehingga memunculkan berbagai faham baru yang berbeda dengan filsafat aslinya (hibrid). Clifford Geertz (1983) ataupun Niel Mulder (1999) menyebut fenomena itu sebagai Sinkretisme. Realitas tersebut semakin mempenjelas, betapa entitas-entitas di Nusantara memiliki kemampuan untuk menemukan dasar kesatuan dibelakang sesuatu yang nampaknya saling bertentangan, sehingga terkesan mempersatukan hal-hal yang berbeda-beda sebagai sebuah relativitas formal. 
Cara berpikir seperti itu, tampaknya juga diinsyafi Ki Hajar Dewantara yang mengembangkan sebuah konsep yang disebutnya "prinsip nasi goreng" dalam memahami sebuah realitas. Nasi goreng adalah makanan asli tradisional yang biasanya digoreng dengan minyak kelapa. Namun, jika mentega (butter) yang berasal dari Belanda dapat membuat nasi goreng itu bertambah enak, maka tidak ada alasan menolak penggunaan mentega itu, selama yang menggorengnya ialah orang Indonesia sendiri. Filsafat Indonesia Tradisional yang bermentega Belanda itu tetap layak untuk disebut "filsafat buatan orang Indonesia", bukannya plagiarisme filsafat Barat.

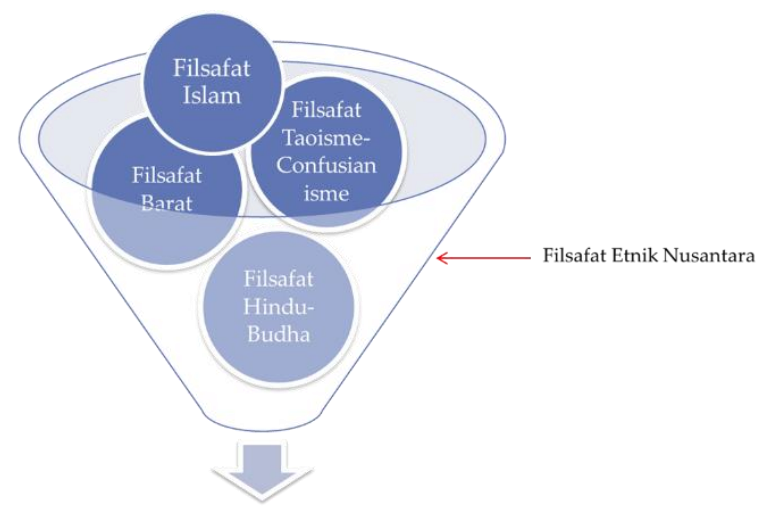

Filsafat Pancasila

\section{Gambar 3. Proses Pembentukan Filsafat Pancasila}

Pandangan hibrid seperti itulah yang kelak dijadikan landasan pemikiran para pendiri negara dalam merumuskan UUD 1945 dan Pancasila. Aspek-aspek FEN terbaik kemudian meresap, mendasari pembentukan negara Indonesia, seperti; tradisi ketuhanan (theisme) dan permusyawaratan (demokrasi pramodern), persatuan antara pimpinan - rakyat, prinsip kekeluargaan, permusyawaratan dan gotong-royong. Sementara sejumlah paham Barat yang relevan, seperti; nasionalisme, humanisme universal atau internasionalisme, rasionalisme, sosialisme negara (staats-socialism) dan kesejahteraan sosial (social democracy) diadopsi dan dicangkokkan. Demikian halnya konsepsi Umran-nya Ibn Khaldun, Maslahah dari ahli fiqih Maliki dan Ibn Taymiyah, serta ljma' Fiqih Islam tentang demokrasi pun diintegrasikan. Gagasan dan konsepsi filosofis hibrid, seperti itulah yang mendasari perumusan UUD 1945 dan Pancasila, sebagai dasar pembentukan NKRI pada 17 Agustus 1945. Untuk itu filsafat Pancasila, dapat dipahami disini sebagai hasil dari proses adaptasi selektif atas "pertemuan" berbagai faham filsafat dunia di Nusantara. Dimana FEN menjadi wadah bagi berlangsungnya transformasi, legitimasi dan habitualisasi gagasan dan konsepsi filosofis hibrid yang membentuk manusia dan bangsa Indonesia sebagaimana mewujud saat ini.

\section{Epistemologi Sistem Ekonomi Pancasila}

Cara pandang hakekat manusia Indonesia seperti itulah, yang melahirkan paham kekeluargaan sebagai esensi dasar kehidupan bermasyarakat dan berbangsa manusia Indonesia. Manusia Indonesia selalu mencari keselarasan antara hidup sebagai pribadi dan hidup sebagai warga masyarakat/negara, antara kehidupan materi dan kehidupan rohani serta yang ber-Ketuhanan Yang Maha Esa. Selain homoeconomicus, manusia Indonesia sekaligus juga homometafisikus dan homo-mysticus (Mangunpranoto, 1981). Dalam kaitan tersebut, untuk mewujudkan cita-cita kemerdekaannya maka interaksi dan interelasi bangsa Indonesia di bidang ekonomipun disusun dalam suatu sistem perekonomian sebagai usaha bersama berdasar atas 
asas kekeluargaan, yang oleh Bung Hatta disebut sebagai Sistem Ekonomi Terpimpin yang juga sering dimaknai sebagai Ekonomi Koperasi (Hatta, 1960).

Sistem ekonomi merupakan susunan pemanfaatan sumberdaya oleh para pelaku ekonomi menggunakan tata cara tertentu, yang sesuai dengan dasar filosofi masyarakatnya, untuk mencapai tujuan bersama yang telah disepakati. Apabila ilmu ekonomi menuntun pemecahan optimal problem pokok semua kegiatan perekonomian, bersifat umum dan berlaku di semua masyarakat ekonomi (negara) dan bebas nilai. Sistem ekonomi justru memberikan pedoman dan jawaban yang berbeda dan berlaku khusus berdasarkan nilai ideologis yang berlaku dalam tiap-tiap masyarakat atau negara. Dasar ideologi yang berbeda akan memberikan jawaban yang berbeda pula. Pemahaman inilah yang dipakai sebagai dasar epistemologi SEP yang dibahas dalam tulisan ini.

Sistem ekonomi menjadi sangat strategis artinya karena memiliki dua fungsi utama, yaitu pedoman untuk mengarahkan perekonomian dan mengkoordinasikan bermacam kegiatan ekonomi yang dilakukan pelaku ekonomi yang mempunyai keinginan (preferensi) yang berbeda-beda. Di dalam sistem ekonomi tersebut, terdapat empat elemen pokok yang menjadi penyusun bangun sistem ekonomi sebuah bangsa, yaitu; 1) kepemilikan sumberdaya; 2) para pelaksana/pelaku; 3) mekanisme pelaksanaan; dan 4) tujuan bersama yang ingin dicapai (Holesovsky, 1977).

Sebagaimana digariskan dalam UUD 1945, SEP memerlukan peranan dua institusi publik untuk mengatur kehidupan perekonomian nasional yaitu; (1) MPR -sebagai lembaga tertinggi negara dan penjelmaan seluruh rakyat Indonesia-menetapkan asas, kaidah, arah, dan haluan negara pembangunan ekonomi nasional dalam UUD 1945 dan Garis-Garis Besar Haluan Negara (GBHN); dan (2) Pasar yang berkeadilan --yang menciptakan kemitraan selaras antar pelaku ekonomi. Diorientasikan untuk mewujudkan kesejahteraan umum sebagaimana diamanatkan Pembukaan dan Pasal 33 UUD 1945, bukan kemakmuran dan kesejahteraan orang per-orang.

Oleh karenanya judul Kesejahteraan Sosial dalam Bab XIV UUD 1945 mempunyai makna yang sangat fundamental, seperti dikatakan Bung Hatta, bahwa sistem ekonomi nasional harus diletakkan sebagai bagian dari kesejahteraan sosial. Dengan landasan pemikiran tersebut, maka Pasal 33 tentang "Perekonomian Nasional", dan Pasal 34 tentang "Jaminan Sosial" diletakkan bersama-sama di bawah Bab XIV dengan judul "Kesejahteraan Sosial" dan Pasal 23 dan 27 dalam batang tubuh UUD 1945 beserta penjelasannya merupakan satu paket gagasan utuh dan menyeluruh sebagai Doktrin Kesejahteraan Sosial (Swasono, 2003)

Setidaknya sejak 1966, ketika Emil Salim melontarkan gagasannya tentang SEP ke ruang publik, telah mendorong berbagai pakar ekonomi - sosial untuk mulai urun-rembug dalam memberikan sumbangan pemikirannya terkait SEP. Jika dirunut, gagasan tersebut dapat dilacak dari pemikiran Bung Hatta, Wilopo, Emil Salim, Soemitro Djojohadikusumo, Mubyarto, Budiono, Dawam Rahardjo, Sri-Edi Swasono, Sritua Arief, dan Subiakto Tjakrawerdaja, yang telah berupaya mengelaborasi dan meninggalkan rekam-jejak akademis dalam memberikan fundamen terhadap konsepgagasan SEP. Pandangan mereka bukan saja telah memperkaya dan menjadi milestone, tetapi juga menimbulkan kontroversi-pertentangan pemikiran yang masih belum tuntas hingga kini. Sebagaimana kritik yang dilontarkan Arief Budiman, Sarbini Sumawinata, Syahrir, William R. Liddle, dan McCawley (baca Tjakrawerdaja, 2019).

Mengacu pada pandangan para pemikir tersebut, maka SEP layak digunakan sebagai dasar pembangunan ekonomi nasional. Sistem ekonomi yang didasarkan pada demokrasi ekonomi, dimana produksi akan dikerjakan dari, oleh, dan untuk seluruh rakyat. Dengan demikian, pembangunan ekonomi nasional akan melibatkan 
partisipasi total seluruh rakyat sehingga setiap warga negara memiliki pekerjaan yang produktif. Sebuah pandangan yang menjadi ciri pokok sistem ekonomi yang sesuai dengan paham kekeluargaan dan bertujuan untuk menjamin terwujudnya kesejahteraan umum.

Oleh karena itu, ciri pokok pertama SEP, adalah adanya pengaturan negara di bidang ekonomi yang harus diputuskan oleh seluruh rakyat secara mufakat. Artinya pengaturan ekonomi tidak boleh hanya diserahkan pada mekanisme pasar semata (seperti dalam sistem ekonomi kapitalisme); dan juga tidak boleh diserahkan sepenuhnya kepada kekuasaan pemerintah (seperti dalam sistem ekonomi sosialisme). Meskipun pengaturan ekonomi oleh negara dalam SEP tetap dilakukan melalui mekanisme pasar, namun pasar yang bercirikan keadilan. Pasar yang mampu memadukan para pelaku ekonomi dalam mengelola sumberdaya guna sebesarbesarnya kemakmuran bersama seluruh rakyat melalui mekanisme kemitraan yang selaras. Konsepsi "pasar berkeadilan" inilah yang menjadi ciri pokok kedua SEP.

Melalui sinergi dua kelembagaan publik tersebut, seluruh rakyat dapat berpartisipasi secara total melalui usaha bersama dalam pembangunan nasional untuk mengolah sumber daya ekonomi dengan produktivitas dan efisiensi kolektif yang tinggi, sehingga tercapai suatu pertumbuhan sekaligus pemerataan berkeadilan (growth through equity). Jadi, dalam SEP, pertumbuhan dan pemerataan bukanlah suatu pilihan yang saling meniadakan, melainkan harus terjadi secara bersamaan guna terwujudnya demokrasi ekonomi. Sebagaimana dikatakan Bung Hatta tujuan pertumbuhan dari pembangunan nasional harus menjadi satu dengan memperbesar kemakmuran rakyat secara seadil-adilnya, secara merata.

Selanjutnya untuk mempermudah dalam mengeksplorasi empat unsur sistem ekonomi yang dikonstruksi Holesovsky, akan diuraikan keberadaan delapan ciri SEP, berikut ini.

1. Setiap warga negara -baik secara perorangan maupun secara kelompokmemiliki pekerjaan yang produktif dan pendapatan yang adil bagi kehidupan kemanusiaan yang layak dan bermartabat;

2. Adanya partisipasi total dari setiap warga negara dalam pembangunan ekonomi;

3. MPR sebagai penjelmaan seluruh rakyat dan lembaga tertinggi negara menguasai, merencanakan, mengatur, dan mengawasi perekonomian nasional;

4. Koperasi Indonesia sebagai sokoguru ekonomi rakyat;

5. Perusahaan negara (BUMN) sebagai sokoguru dalam kegiatan-kegiatan ekonomi yang penting dan menguasai hajat hidup orang banyak;

6. Perusahaan swasta yang berasaskan kekeluargaan berperan sebagai penggerak utama pertumbuhan kegiatan ekonomi yang tinggi di luar cabangcabang produksi yang penting dan menguasai hajat hidup orang banyak;

7. Menggunakan institusi pasar berkeadilan;

8. Adanya perlindungan sosial bagi rakyat yang tidak dapat bekerja produktif atau kehilangan pekerjaan.

Untuk mewujudkan tujuan pembangunan nasional, selanjutnya SEP mengarahkan sasaran pembangunan ekonomi (secara aksiologis) pada hal-hal strategis berikut ini. Pertama, tersedianya lapangan kerja yang luas, sehingga seluruh rakyat memiliki pekerjaan dan ikut serta dalam proses pembangunan, serta menikmati hasilnya. Kedua, peningkatan pendapatan. untuk dapat mencapai pertumbuhan ekonomi yang memadai. Ketiga, peningkatan pendapatan devisa. yang tidak hanya tumbuh dari impor barang-barang dan jasa yang belum dapat diproduksi di dalam negeri, namun juga harus dapat menghasilkan produk ekspor yang menghasilkan devisa dalam jumlah mencukupi. Keempat, stabilitas ekonomi makro dalam rangka 
menciptakan kelancaran dan meredam gejolak ekonomi. Kelima, lingkungan hidup yang nyaman dan lestari. Dimana desain arah dan haluan pembangunan ekonomi nasional dapat dirumuskan dalam kebijakan, dan strategi pembangunan di sektor industri, perdagangan, keuangan, fiskal, serta jaminan sosial yang berpedoman pada UUD 1945.

Tentu untuk dapat memahami lebih komprehensif dan objektif atas aspek ontologis dari penerapan SEP dalam pembangunan perekonomian nasional, membutuhkan kajian interdisipliner yang melibatkan berbagai pakar dari beragam disiplin ilmu. Hasil evaluasi perjalanan pembangunan nasional setelah kemerdekaan yang diperoleh dari kajian seperti ini akan sangat penting artinya sebagai dasar teleologis bangsa Indonesia dalam mewujudkan cita-cita kemerdekannya.

\section{SIMPULAN}

Berdasarkan uraian di atas, maka SEP berbeda dengan sistem ekonomi kapitalisme, sosialisme, maupun sistem ekonomi alternatif yang berangkat dari landasan ontologis hakekat manusia yang berbeda. Penalaran SEP lebih memilih jalannya sendiri sebagai sebuah sistem ekonomi yang secara ilmiah berangkat dari asal-usul filosofis khas Indonesia, sehingga disebut Bung Hatta sebagai "sistem sendiri". Secara konsepsional SEP telah memenuhi elemen-elemen dari susunan sistem ekonomi yang terdiri dari; (1) tujuan, yaitu untuk kemakmuran bersama seluruh rakyat; (2) kepemilikan sumber daya yang didasarkan pada hak penguasaan sumberdaya oleh negara; (3) pelaku ekonomi, yang meliputi BUMN, koperasi, dan swasta yang bermitra usaha secara selaras; serta (4) mekanisme penyelenggaraan kegiatan ekonomi dalam pasar berkeadilan.

SEP merupakan sebuah gagasan yang setara dengan konsep "Jalan Ketiga"nya Anthony Gidden, bahkan menurut Rahardjo (2004) jika mampu diaktualisasikan secara konsisten memiliki "kesejajaran" dengan pemikiran pembangunan internasional yang mengandung nilai aktualitas dan relevansi dengan gagasan yang mampu mengatasi pemikiran kiri-kanan (beyond right and left), sebagaimana Teori Ketergantungan, tapi otentik Indonesia. SEP tidak menggunakan mekanisme pasar bebas, sebagaimana direkomendasikan banyak peraih Nobel, seperti; Gunnar Myrdal, Joseph E. Stiglitz, Amartya Sen, Paul Krugman, dan Jean Tirole. (Swasono, 2013). Konsepsi SEP yang berdimensi kerakyatan, juga sejalan dengan konsep pemikiran pembangunan ekonomi alternatif dari pakar-pakar ekonomi, seperti John Friedman, Sharp J.S., David C. Korten, dan Robert M Grant (Yustika, 2013). 


\section{DAFTAR PUSTAKA}

Dahana, Panca Radhar. (2016). Pertahanan Budaya Kita dalam kolom opini Kompas, 9 Februari 2016.

Dick-Read, Robert. (2008). Pengaruh Peradaban Nusantara di Afrika: Penjelajah Bahari. Bandung: Mizan.

Djafar, T.B. Massa, Diana Fauziah, Subikato Tjakrawerdaja, Soenarto Soedarno, Ganjar Razumi dan P. Setia Lenggono. (2020). Sistem Demokrasi Pancasila. Depok: Rajawali Pers.

Geerz, Clifford. (1983). Abangan Santri Priyayi dalam Masyarakat Jawa, Jakarta: Pustaka Jaya.

Hatta, Mohammad. (1960). Ekonomi Terpimpin. Jakarta. Penerbit Fasco. Djakarta.

Hazairin. (1970). Demokrasi Pancasila. Jakarta: Tinta Mas.

Holesovsky, Vaclav. (1997). Economic System: Analysis and Comparison. McGrawHill.

Irwan, Alexander. (1999). "Mencari Pendekatan yang Lebih Historis" Pengantar dalam Robert W. Hefner (editor). Budaya Pasar: Masyarakat dan Moralitas dalam Kapitalisme Asia Baru. Jakarta: LP3ES.

Kartika, Dwi Danang. (2004). Pencarian Dasar-Dasar Filosofis Bagi Keberadaan Filsafat Nusantara. Wacana: Jurnal IImu Pengetahuan Budaya, Vol. 6, No. 2, Oktober 2004.

Lombard Dennys, 1996. Le Carrefour Javanais (edisi Indonesia: Nusa Jawa Silang Budaya), Jakarta: Gramedia.

Mangunpranoto, Sarino. (1981). "Dasar Falsafah Ekonomi Pancasila" dalam Mubyarto dan Boediono (Ed.). Ekonomi Pancasila. Yogyakarta: BPFE.

Mubyarto dan Boediono (Editor), 1980. Ekonomi Pancasila. Yogyakarta: Bagian Penerbit Fakultas Ekonomi UGM

Mulder Niel, 1999. Agama, Hidup Sehari-Hari dan Perubahan Budaya: Jawa, Muangthai dan Filipina, Jakarta: Gramedia Pustaka Utama.

Notonagoro. (1975). Pancasila Secara IImiah Populer. Jakarta: Penerbit Pantjuran Tujuh.

Rahardjo, M. Dawam. (2004). Ekonomi Pancasila: Jalan Lurus Menuju Masyarakat Adil dan Makmur. Yogyakarta: Adytia Media dan Pustep UGM.

Reid Antony, 2011. Asia Tenggara dalam Kurun Waktu Niaga 1450 - 1680 jilid satu: Tanah di Bawah Angin, Jakarta: Yayasan Obor Indonesia, 2011.

Swasono Sri Edi, 2003. Ekspose Ekonomika, Globalisme dan Kompetensi Sarjana Ekonomi. Yogyakarta: Penerbit Pusat Studi Ekonomi Pancasila-UGM.

Swasono Sri Edi. 2013, "Bahan Ajar Sistem Ekonomi" Fakultas Ekonomi, Universitas Indonesia, 11 Desember 2013

Tjakrawerdaja, Subiakto, Soenarto Soedarno, P. Setia Lenggono, Budhi Purwandaya, M. Karim dan Lestari Agusalim. (2019). Sistem Ekonomi Pancasila (edisi kedua). Depok: Rajawali Pers.

Yustika, Erani Ahmad. (2012). Ekonomi Kelembagaan: Paradigma, Teori, dan Kebijakan. Jakarta: Penerbit Erlangga. 